\title{
Co-inoculation of Rhizobium tropici and Azospirillum brasilense in common beans grown under two irrigation depths ${ }^{1}$
}

\author{
Amanda Ribeiro Peres ${ }^{2 *}$, Ricardo Antonio Ferreira Rodrigues ${ }^{3}$, Orivaldo Arf ${ }^{3}$, José Roberto Portugal ${ }^{2}$, \\ Daiene Camila Dias Chaves Corsini ${ }^{2}$
}

$10.1590 / 0034-737 X 201663020011$

\begin{abstract}
The alternative technique of co-inoculation or mixed inoculation with symbiotic and non-symbiotic bacteria has been studied in leguminous plants. However, there are few field studies with common beans and under the influence of the amount of irrigated water. Thus, the objective of this study was to evaluate the efficiency of inoculation and coinoculation of common beans with Rhizobium tropici and Azospirillum brasilense under two irrigation depths. The experiment was carried out in the winter of 2012 and 2013, in Selvíria, state of Mato Grosso do Sul. The experimental design was composed of randomized blocks in split-plot scheme with two irrigation depths in the plots (recommended for common beans and $75 \%$ of the recommended) and five forms of nitrogen $(\mathrm{N})$ supply in the split-plots (control noninoculated with $40 \mathrm{~kg} \mathrm{ha}^{-1}$ of $\mathrm{N}$ in topdressing, $80 \mathrm{~kg} \mathrm{ha}^{-1}$ of $\mathrm{N}$ in topdressing, A. brasilense inoculation with $40 \mathrm{~kg}$ ha${ }^{1}$ of $\mathrm{N}$ in topdressing, $R$. tropici inoculation with $40 \mathrm{~kg} \mathrm{ha}^{-1}$ of $\mathrm{N}$ in topdressing, and co-inoculation of A. brasilense and R. tropici with $40 \mathrm{~kg} \mathrm{ha}^{-1}$ of $\mathrm{N}$ in topdressing) with four repetitions. Co-inoculation increased nodulation in the second year of cultivation. None of the evaluated treatments increased the grain yield in relation to non-inoculated control with $40 \mathrm{~kg} \mathrm{ha}^{-1}$ of nitrogen in topdressing, which presented average yield of $2,200 \mathrm{~kg} \mathrm{ha}^{-1}$. The use of $75 \%$ of the recommended irrigation depth provides similar grain yield to the recommended irrigation depth in common beans cropped in winter.
\end{abstract}

Key words: Phaseolus vulgaris $\mathrm{L}$., nitrogen, $\mathrm{N}_{2}$ biological fixation, plant growth-promoting bacteria, water.

\section{RESUMO}

\section{Co-inoculação de Rhizobium tropici e Azospirillum brasilense em feijoeiro cultivado sob duas lâminas de irrigação}

A técnica alternativa de co-inoculação ou também denominada de inoculação mista com bactérias simbióticas e assimbióticas tem sido estudada em leguminosas, no entanto, existem poucos estudos em campo com feijoeiro e sobre a influência da quantidade de água irrigada. Dessa forma, objetivou-se com este experimento avaliar a eficiência da inoculação e co-inoculação de feijão com Rhizobium tropici e Azospirillum brasilense sob duas lâminas de irrigação. $\mathrm{O}$ experimento foi desenvolvido no período de outono/inverno dos anos de 2012 e 2013, no município de Selvíria (MS). O delineamento experimental foi em blocos casualizados em esquema de parcelas subdivididas, correspondente a duas lâminas de irrigação nas parcelas (recomendada para o feijão e $75 \%$ da recomendada) e cinco formas de fornecimento de nitrogênio (N) nas subparcelas (testemunha sem inoculação com $40 \mathrm{~kg} \mathrm{ha}^{-1}$ de $\mathrm{N}$ em cobertura, $80 \mathrm{~kg} \mathrm{ha}^{-1}$ de N em cobertura sem inoculação, inoculação de $A$. brasilense com $40 \mathrm{~kg} \mathrm{ha}^{-1} \mathrm{de} \mathrm{N}$ em cobertura, inoculação de $R$. tropici com $40 \mathrm{~kg} \mathrm{ha}^{-1}$ de N em cobertura, e co-inoculação de $A$. brasilense e $R$. tropici com $40 \mathrm{~kg} \mathrm{ha}^{-1} \mathrm{de} \mathrm{N}$ em cobertura), com quatro repetições. A co-inoculação proporcionou aumento da nodulação no segundo ano de cultivo. Nenhum dos tratamentos

\footnotetext{
Submitted on February $5^{\text {th }}, 2014$ and approved on January $18^{\text {th }}, 2016$.

${ }^{1}$ Part of the dissertation of the first author.

${ }^{2}$ Universidade Estadual Paulista "Júlio de Mesquita Filho", Ilha Solteira, São Paulo, Brazil. amandarperes_agro@yahoo.com.br; jr_portugal@hotmail.com; daiene6@hotmail.com

${ }^{3}$ Universidade Estadual Paulista "Júlio de Mesquita Filho”, Ilha Solteira, São Paulo, Brazil. ricardo@agr.feis.unesp.br; arf@agr.feis.unesp.br

* Corresponding author: amandarperes_agro@yahoo.com.br
} 
avaliados aumentou a produtividade em relação à testemunha não inoculada com $40 \mathrm{~kg} \mathrm{ha}^{-1}$ de nitrogênio em cobertura, que apresentou produtividade média de $2.200 \mathrm{~kg} \mathrm{ha}^{-1}$. A utilização de $75 \%$ da lâmina recomendada proporciona produtividade de grãos semelhante a lâmina recomendada em feijoeiro de inverno.

Palavras-chave: Phaseolus vulgaris L., nitrogênio, fixação biológica de $\mathrm{N}_{2}$, bactéria promotora de crescimento, água.

\section{INTRODUCTION}

Brazil was the world's third largest bean producer in 2014, surpassed only by India and Myanmar (Food and Agriculture Organization - FAO, 2014). However, despite this distinction, bean crop in Brazil presents average productivity relatively low. According to the Companhia Nacional de Abastecimento-Conab (Brazilian Supply Company) (2015) in the 2014/2015 season, the Brazilian average yield of beans was $1,050 \mathrm{~kg} \mathrm{ha}^{-1}$, considering the various farming systems of this leguminous.

One of the most important agricultural inputs that results in the achievement of high bean yields is the nitrogen fertilizer. However, in spite of being assimilated more quickly by the plants, nitrogen fertilizers are expensive, presents high cost of energy sources in its manufacturing, low use efficiency by plants, besides being related to environmental pollution (Hungria et al., 2007). In addition, alternatives that reduce the application of inputs in the areas of agricultural production are highly searched. An alternative to reduce the need for nitrogen fertilizers is the biological nitrogen fixation, performed by a select group of bacteria, named diazotrophic (Reis, 2007).

In addition to specific rhizobia for leguminous plants, there are other microorganisms that can bring benefits to crops. One of the most promising group is represented by associative bacteria, capable of promoting the growth of plants by means of various processes such as the production of growth hormones (auxins, gibberellins, cytokinins and ethylene), capacity of solubilizing phosphate and performing biological nitrogen fixation, among other processes. Among these bacteria, those that belong to the genus Azospirillum (Hungria \& Nogueira, 2013) stand out.

In this scenario, an alternative technique of coinoculation, also named mixed inoculation with symbiotic and asymbiotic bacteria, has been studied in leguminous plants. This technique is the use of combinations of different microorganisms that produce a synergistic effect, which outweigh the productive results when used alone (Ferlini, 2006; Bárbaro et al., 2008). Because of the positive interaction between bacteria, co-inoculation has been suggested to enhance the nodulation, to stimulate plant growth and to benefit the biological process of nitrogen fixation (Costa et al., 2014). In cases where Azospirillum brasilense has been used in legumes, the beneficial effect of the association is mostly due to the capacity of the bacteria to produce plant hormones (Bárbaro et al., 2008) such as auxin, gibberellin and cytokinins (Bashan \& Bashan, 2005), which results in increased root growth, and therefore, the possibility of exploiting larger volume of soil. (Bárbaro et al., 2008).

Some studies have reported the benefits of coinoculation of rhizobia with plant growth promoting bacteria, such as in soybean crops, which favors the precocity of nodulation (Chibeba et al., 2015), the increase in the number of nodes (Costa et al., 2014); nitrogen fixation and nodulation, the leghemoglobin content in the nodules (Groppa et al., 1998) and grain yield (Araújo \& Hungria, 1999; Hungria et al. 2013; Hungria et al., 2015). Nevertheless, co-inoculation with Rhizobium strain Rb133 and Pseudomonas fluorescens strain P-93 resulted in increased nodulation, greater dry matter mass of the aerial part and nitrogen fixation (Yadegari et al., 2010) in beans, which resulted in higher productivity ( Yadegari et al., 2010; Yadegari, 2014). However, there are few studies with products commercially available in Brazil, as inoculants containing bacteria fitted to Brazilian conditions such as Azospirillum brasilense and Rhizobium tropici.

Besides nitrogen, yield of bean crop is influenced by the soil water condition. Deficiency or excess of water at the different stages of the crop, reduce yield at different proportions (Paula Júnior, et al., 2008). Water shortage also affects growth and the role of symbiosis (Hungria \& Vargas, 2000) and affects the absorption of nutrients.

Thus, the objective with this work was to evaluate the efficiency of inoculation and co-inoculation of beans with Rhizobium tropici and Azospirillum brasilense under two irrigation depths.

\section{MATERIAL AND METHODS}

The experiment was carried out in fall/winter of 2012 and 2013 at the Farm Teaching and Research of the Faculdade de Ilha Solteira - UNESP, located in the municipality of Selvíria, state of Mato Grosso do Sul, which has the approximate geographical coordinates of $51^{\circ} 24^{\prime} \mathrm{W}$ and $20^{\circ} 20^{\prime} \mathrm{S}$ and 340 meters above sea level. The original soil 
in the area is a clay texture Oxisoil, according to EMBRAPA classification.

The climate in the region, according to Koppen classification is Aw, defined as tropical humid with rainy season in the Summer and dry season in the Winter. The average annual rainfall is $1,313 \mathrm{~mm}$, with an average annual temperature of $25^{\circ} \mathrm{C}$ and average minimum and maximum temperatures of $19^{\circ} \mathrm{C}$ and $31^{\circ} \mathrm{C}$, respectively (Portugal et al., 2015).

Before the experiment establishment in 2012, sample of the soil in the area was collected in the $0-0.20 \mathrm{~m}$ layer for chemical analysis. The results showed: $\mathrm{P}($ resin $)=12.4 \mathrm{mg}$ $\mathrm{dm}^{-3}$, O.M. $=16.4 \mathrm{~g} \mathrm{dm}^{-3}, \mathrm{pH}\left(\mathrm{CaCl}_{2}\right)=5.0 ; \mathrm{K}, \mathrm{Ca}, \mathrm{Mg}, \mathrm{H}+$ $\mathrm{Al}, \mathrm{SB}$ and $\mathrm{CEC}=1.5 ; 18.2 ; 11.8 ; 18.2 ; 31.5$ and $49.7 \mathrm{mmol}_{\mathrm{c}}$ $\mathrm{dm}^{-3}$, respectively, and $\mathrm{V}=63 \%$.

In the two years, the same area was used and soil tillage was carried out by scarification and disking leveling, where corn was the previous crop.

The experimental design was a randomized block with treatments arranged in a split-plot design, corresponding to two water depths in the plots (recommended for bean and $75 \%$ of the recommended) and five forms of nitrogen supply in the subplots (control without inoculation with $40 \mathrm{~kg} \mathrm{ha}^{-1}$ of nitrogen in topdressing, $80 \mathrm{~kg} \mathrm{ha}^{-1} \mathrm{~N}$ without inoculation, inoculation of $A$. brasilense with $40 \mathrm{~kg} \mathrm{ha}^{-1}$ of nitrogen in topdressing, inoculation of $R$. tropici with 40 $\mathrm{kg} \mathrm{ha}^{-1}$ of nitrogen in topdressing and co-inoculation of $A$. brasilense and $R$. tropici with $40 \mathrm{~kg} \mathrm{ha}^{-1} \mathrm{~N}$ in topdressing), with four replications.

The experimental units consisted of five rows of $6.2 \mathrm{~m}$ long, spaced by $0.50 \mathrm{~m}$ from each other in 2012 and by 0.45 $\mathrm{m}$ in 2013. The useful area were the three central rows of each plot, in which two rows were for productivity and one to collect plants and roots, disregarding $0.5 \mathrm{~m}$ of each edge.

Cultivar 'Pérola' beans were sown mechanically, with a quantity of seeds sufficient to obtain 10 and 13 plants $\mathrm{m}^{-1}$ on days May 2, 2012 and May 22, 2013 respectively. Seeds were not chemically treated. Sowing fertilization followed the analysis of soil, with $250 \mathrm{~kg} \mathrm{ha}^{-1}$ from 04-30-10 formula in two years of cultivation based on the recommendations by Ambrosano et al. (1997) for the expected yield of 2,500 $\mathrm{kg} \mathrm{ha}^{-1}$. In the second year, the experiment was allocated in an area with fertility levels equal to the first year of cultivation.

Seeds were inoculated with Azospirillum brasilense with peat inoculant containing $\mathrm{AbV}_{5}$ and $\mathrm{AbV}_{6}$ strains at a dose of $200 \mathrm{~g}$ per $25 \mathrm{~kg}$ of seeds in 2012. In 2013, liquid inoculant for grasses was used, which also contained the same strains $\left(\mathrm{AbV}_{5}\right.$ and $\left.\mathrm{AbV}_{6}\right)$ at a dose of $200 \mathrm{~mL}$ for $25 \mathrm{~kg}$ of seed. For the inoculation with Rhizobium tropici, the commercial peat inoculant was used with Semia 4080 strain at a dose of $200 \mathrm{~g}$ for $25 \mathrm{~kg}$ of seeds. The co-inoculation was performed by mixing the two bacteria at the same proportions used when inoculated alone, that is, $200 \mathrm{~g}$ (or $200 \mathrm{~mL}$ ) of inoculant containing A. brasilense $+200 \mathrm{~g}$ of inoculant containing $R$. tropici for $25 \mathrm{~kg}$ of seeds. The inoculation was performed by mixing the inoculant with sugar solution at $12 \%$ at the proportion of $250 \mathrm{~mL}$ of solution for every $500 \mathrm{~g}$ of inoculant.

Emergence occurred on days seven and six after sowing in 2012 and 2013, respectively. Nitrogen in topdressing fertilization was performed on days 24 and 20 days after emergence (DAE) for the years 2012 and 2013, respectively, when the plants were at $\mathrm{V}_{4-4}$ stage (fourth trifoliate leaf). Urea was used as nitrogen source. Thereupon fertilization in the surface and between the lines, the area was irrigated to reduce losses by ammonia volatilization.

Water was supplied by a fixed system of conventional irrigation sprinkler with an average precipitation of $3.3 \mathrm{~mm}$ $\mathrm{h}^{-1}$ in the sprinklers. Water replenishment was performed when the accumulated crop evapotranspiration (ETc) reached values close to the pre-established available soil water (ASW). Water evaporation (ECA) was obtained daily from class A tank installed in the Weather Station, $500 \mathrm{~m}$ away from the experimental area. The coefficient of Class A tank (Kp) used was proposed by Doorenbos \& Pruitt (1976).

In the crop water management for the recommended depth, the following crop coefficients $(\mathrm{Kc})$ were used: 0.30; $0.70 ; 1.05 ; 0.75$ and 0.25 (Doorenbos \& Kassam, 1979) for the following growth stages: germination - primary leaves (V0 - V2); first trifoliate leaf - third trifoliate leaf (V3 -V4); pre-flowering - pod formation (R5 - R7); pod filling (R8) and maturation (R9) (Fernandez et al., 1986), respectively. In the depth of $75 \%$ of the recommended one, Kc crop coefficients values were $25 \%$ lower than $\mathrm{Kc}$ of the recommended depth.

Control of weeds, pests and diseases was conducted according to the crop needs. The harvest was performed manually on day 89 after emergence (DAE) in 2012 and day 81 after emergence in 2013.

The following variables were evaluated:

1) Final population of plants: evaluated by counting the plants in two rows of the useful area of plots at harvest time, and the data were transformed into plants ha ${ }^{-1}$;

2) Number of nodules per plant, dry matter of nodules per plant and root dry matter: at the full flowering stage (R6) in three blocks, roots of five plants were collected in sequence in the useful area of each plot, using mattock at the $0-20 \mathrm{~cm}$ depth. Then the roots were washed in tap water and sieves, and after that, the following were determined: the number of nodules per plant, by counting; dry weight of nodules and root dry matter by drying in an 
oven at $65{ }^{\circ} \mathrm{C}$ for 72 hours and after that, weighing. The data were transformed into number of nodules per plant, dry matter of nodules per plant and dry matter of roots per plant $(\mathrm{g})$;

3) Dry matter of the aerial part per plant and leaf nitrogen content: at the full flowering stage (R6), the aerial part of ten plants were collected, packed in paper bag and taken to the laboratory and submitted to drying in an air forced ventilation oven at an average temperature of $65^{\circ} \mathrm{C}$ until constant mass. After that, dry matter mass was quantified and the values were converted into $g$ / plant. To evaluate the leaf $\mathrm{N}$ content, all the leaves were picked from the plants previously dried to determine the mass of dry matter, and then they were ground in Wiley-type mil. After that, they were submitted to nitrogen analysis using the methodology proposed by Malavolta et al. (1997);

4) Production components: at harvest, 10 plants were collected at a predetermined location in the useful area of each plot and taken to the laboratory for determination of the number of pods per plant and number of grains per pod;

5) Mass of 100 grains: weighing of two 100-grain samples in each experimental unit;

6) Yield: Plants within two rows of three meters in length in the useful area of each experimental unit were collected and dried in full sun, and then mechanically threshed. After this, the beans were weighed and the data transformed into $\mathrm{kg} \mathrm{ha}^{-1}$. For the 100-grain mass and yield, data were adjusted to $13 \%$ moisture (wet basis).

Data were evaluated by analysis of variance. When the F value was significant ( $\mathrm{p}<0.05$ ), the Tukey test was used for comparison of means. Statistical analysis was performed using the software SISVAR (Ferreira, 2011).

\section{RESULTS AND DISCUSSION}

The average final population in 2012 was 182,593 plants ha $^{-1}$ and in 2013, 210,833 plants ha ${ }^{-1}$ (Table 1). The smallest population in 2012 is due to the seeder used in the experiment (seed distribution disc), which was less accurate than that used in 2013 (vacuum distribution pneumatic seeder). According to Souza et al. (2002), the range from 100,000 to 400,000 plants ha $^{-1}$ results in equivalent yields. This is due to the compensation capacity of the primary components of bean production, which provides equal productivity using different populations (Arf et al., 2011).

It can be seen that only in 2013, a significant difference was found in the final population of plants among the evaluated treatments (Table 1), in which the inoculation with A. brasilense resulted in smaller population. Gitti et al. (2012) also achieved a lower population of bean plants with the inoculation of $A$. brasilense when compared to treatment without seed inoculation using Cranberry and ETA10 cultivars

In 2012, a significant interaction between the irrigation depth and the form of nitrogen supply on the dry matter of the aerial part was found (Table 1). When the form of nitrogen supply was analyzed within the recommended depth (Table 2), it is found that co-inoculation resulted in higher dry matter mass of the aerial part than the control, the application of $80 \mathrm{~kg} \mathrm{ha}^{-1}$ of $\mathrm{N}$ in topdressing and inoculation with $R$. tropici, and it did not differ from $A$. brasilense, while with $75 \%$ of the recommended depth, the treatments with $A$. brasilense and $R$. tropici resulted in greater mass than the control, and $80 \mathrm{~kg} \mathrm{ha}^{-1} \mathrm{~N}$ in topdressing, and did not differ from co-inoculation. This result may be associated with the benefits promoted by bacteria, such as nitrogen fixation and production of hormones. Likewise, Souza et al. (2012) also found that inoculation with Rhizobium tropici in Pérola beans resulted in greater dry mass of the aerial part than the control without inoculation. On the other hand, Veronezi et al. (2012) did not obtain differences in the mass of the aerial part between treatments with inoculation of bean seeds with $R$. tropici, co-inoculation of $R$. tropici and $A$. brasilense, without inoculation added or not to mineral $\mathrm{N}$. Regarding the unfolding of the irrigation depth effect within the form of nitrogen supply, the $75 \%$ depth provided lower dry matter of the aerial part only in the co-inoculation (Table 2). This result may have been caused by competition between the bacteria for water, which minimized the production of plant hormones and nitrogen fixation.

In 2013, the dry matter of the aerial part was influenced by the form of nitrogen supply, in which inoculation with A. brasilense was higher than in the other treatments (Table 1). This effect can be attributed to substances produced by Azospirillum, which, according to Oliveira et al. (2008), bacteria of this genus produce three types of substances that stimulate plant growth: auxins (3-indoleacetic acid), cytokine, and gibberellin, in which auxin is the most important at the quantitative level This result may also be related to smaller plant population obtained with this treatment, where each plant had larger space for growth, which combined with its compensation capacity, resulted in greater accumulation of dry matter mass.

In both experimental years, an interaction between the form of nitrogen supply and irrigation depth was found for root growth (Table 1). When observing the effect of the form of nitrogen supply in each water depth in 2012 (Table 2), it was found that the recommended depth to co-inoculation resulted in a higher root dry matter when compared to the control and $R$. tropici, but it was not different from A. brasilense and $80 \mathrm{~kg} \mathrm{ha}^{-1}$ of 
$\mathrm{N}$ in topdressing. In addition, in the $75 \%$ of the recommended depth, no differences in the form of nitrogen supply were found. Regarding the unfolding of the water depth effect on each form of nitrogen supply, it is observed that in the co-inoculation, the use of $75 \%$ of the recommended water depth decreased the dry matter mass of the root (Table 2). Similar to what happened in this experiment, Souza et al. (2012) found no differences between the presence and absence of rhizobial inoculant on the root dry matter. Dardanelli et al. (2008) reported greater root dry matter with coinoculation in normal salinity conditions, and in salt stress conditions, co-inoculation and inoculation with A. brasilense were able to provide greater root dry mass.

The unfolding of the effect of the form of nitrogen supply within irrigation depth on the root dry matter mass in 2013 displayed a higher root development for $80 \mathrm{~kg}$ ha${ }^{1} \mathrm{~N}$ in topdressing treatment in both evaluated depths. In relation to the water depth effect in each form of nitrogen supply, the use of the recommended depth associated with $80 \mathrm{~kg} \mathrm{ha}^{-1}$ of $\mathrm{N}$ in topdressing and depth of $75 \%$ of the recommended associated with the co-inoculation resulted in a smaller value of root dry matter mass (Table 2). The highest root dry matter mass provided by the application of $80 \mathrm{~kg} \mathrm{ha}^{-1}$ of nitrogen in topdressing can be attributed to the fact that fertilizer is more readily available to plants, contributing to a higher initial growth. However, the fact that lower depth provides greater root dry matter mass may have occurred due to the lower water irrigated volume, which increased with rainfall, could have resulted in less nutrient leaching.

Similar to what happened with the root dry matter mass, a significant interaction was found between form of nitrogen supply and irrigation depth on the leaf nitrogen content in both years (Table 1). When analyzing the form of nitrogen supply within the recommended water depth in 2012, no differences were found between treatments. On the other hand, in the depth of $75 \%$ of the recommended, application of $80 \mathrm{~kg}$ of nitrogen $\mathrm{ha}^{-1}$ in topdressing provided higher leaf nitrogen content than the others. By observing the effect of the irrigation depth in each form of nitrogen supply, it is noted that application of $80 \mathrm{~kg} \mathrm{ha}^{-1}$ of nitrogen in topdressing with the recommended water depth resulted in lower leaf nitrogen content than the depth of $75 \%$ of the recommended (Table 2). This result may be related to the fact that the smaller amount of irrigation resulted in lower nutrient leaching. Hungria et al. (2013) found no differences between the non-inoculation, nitrogen fertilization, inoculation without nitrogen fertilization, inoculation with $A$. brasilense, inoculation with

Table 1: Final population (FP), dry matter mass of the aerial part (DMAP), root dry matter mass (RDM) and content of leaf nitrogen (N) of beans 'Pérola' according to the nitrogen supply and water depths

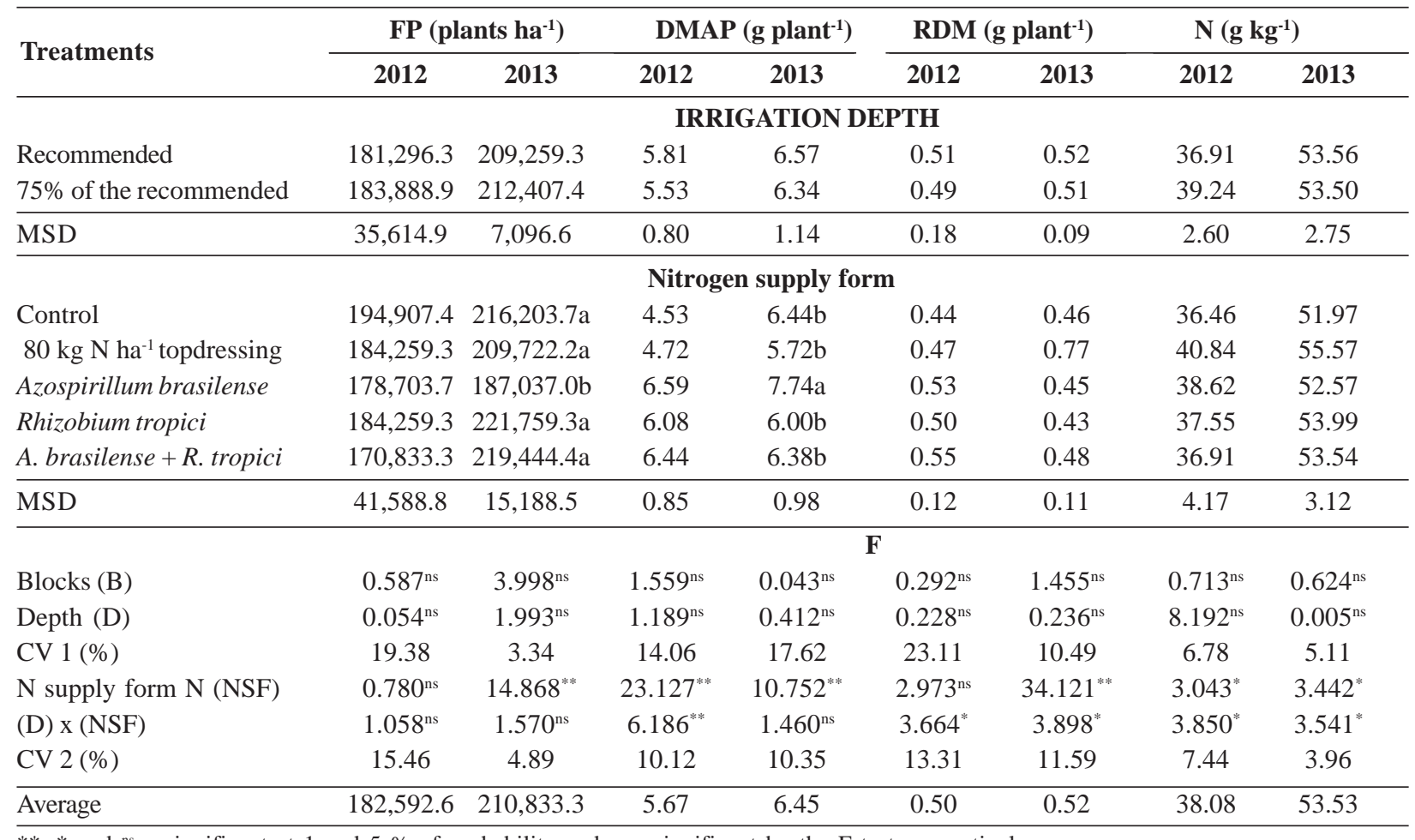

**, * and ${ }^{\mathrm{ns}}$ - significant at 1 and $5 \%$ of probability and non-significant by the $\mathrm{F}$ test, respectively;

Means followed by the same letter in the columns do not differ by the test of Tukey at 5\% of probability; M.S.D. - Minimum significant difference; C.V. - coefficient of variation.

Rev. Ceres, Viçosa, v. 63, n.2, p. 198-207, mar/abr, 2016 
Table 2: Unfolding of significant interactions between nitrogen supply and water depth for dry matter mass of the aerial part in 2012, root dry matter mass in 2012, root dry matter mass in 2013, leaf nitrogen content in 2012 and leaf nitrogen content in 2013 for beans Pérola cultivar

\begin{tabular}{|c|c|c|c|c|c|}
\hline \multirow{3}{*}{ Depths } & \multicolumn{5}{|c|}{ Dry matter mass of the aerial part in $2012\left(\mathrm{~g} \mathrm{plant}^{-1}\right)$} \\
\hline & \multicolumn{5}{|c|}{ Nitrogen supply form } \\
\hline & Control & $80 \mathrm{~N}$ & A. brasilense & R. tropici & A. brasilense $+R$. tropici \\
\hline Recommended & $4.23 \mathrm{Da}$ & $4.89 \mathrm{CDa}$ & $6.76 \mathrm{ABa}$ & $5.79 \mathrm{BCa}$ & 7.38Aa \\
\hline \multirow[t]{4}{*}{$75 \%$ of the recommended } & $4.82 \mathrm{Ba}$ & $4.56 \mathrm{Ba}$ & $6.42 \mathrm{Aa}$ & $6.37 \mathrm{Aa}$ & $5.50 \mathrm{ABb}$ \\
\hline & \multicolumn{5}{|c|}{ Root dry matter mass in $2012\left(\mathrm{~g} \mathrm{plant}^{-1}\right)$} \\
\hline & \multicolumn{5}{|c|}{ Nitrogen supply form } \\
\hline & Control & $80 \mathrm{~N}$ & A. brasilense & R. tropici & A. brasilense $+R$. tropici \\
\hline Recommended & $0.40 \mathrm{Ca}$ & $0.47 \mathrm{ABCa}$ & $0.58 \mathrm{ABa}$ & $0.46 \mathrm{BCa}$ & $0.63 \mathrm{Aa}$ \\
\hline \multirow[t]{4}{*}{$75 \%$ of the recommended } & $0.48 \mathrm{Aa}$ & $0.46 \mathrm{Aa}$ & $0.48 \mathrm{Aa}$ & $0.54 \mathrm{Aa}$ & $0.48 \mathrm{Ab}$ \\
\hline & \multicolumn{5}{|c|}{ Root dry matter mass in $2013\left(\right.$ g plant $\left.^{-1}\right)$} \\
\hline & \multicolumn{5}{|c|}{ Nitrogen supply form } \\
\hline & Control & $80 \mathrm{~N}$ & A. brasilense & R. tropici & A. brasilense $+R$. tropici \\
\hline Recommended & $0,45 \mathrm{Ba}$ & $0,70 \mathrm{Ab}$ & $0,47 \mathrm{Ba}$ & $0,44 \mathrm{Ba}$ & $0,55 \mathrm{Ba}$ \\
\hline \multirow[t]{4}{*}{$75 \%$ of the recommended } & $0,46 \mathrm{Ba}$ & $0,84 \mathrm{Aa}$ & $0,42 \mathrm{Ba}$ & $0,42 \mathrm{Ba}$ & $0,42 \mathrm{Bb}$ \\
\hline & \multicolumn{5}{|c|}{ Leaf nitrogen content in $2012\left(\mathrm{~g} \mathrm{~kg}^{-1}\right)$} \\
\hline & \multicolumn{5}{|c|}{ Nitrogen supply form } \\
\hline & Control & $80 \mathrm{~N}$ & A. brasilense & R. tropici & A. brasilense $+R$. tropici \\
\hline Recommended & $36.59 \mathrm{Aa}$ & $36.21 \mathrm{Ab}$ & $37.89 \mathrm{Aa}$ & $37.40 \mathrm{Aa}$ & $36.45 \mathrm{Aa}$ \\
\hline \multirow[t]{4}{*}{$75 \%$ of the recommended } & $36.33 \mathrm{Ba}$ & 45.48Aa & $39.36 \mathrm{Ba}$ & $37.70 \mathrm{Ba}$ & $37.36 \mathrm{Ba}$ \\
\hline & \multicolumn{5}{|c|}{ Leaf nitrogen content in $2013\left(\mathrm{~g} \mathrm{~kg}^{-1}\right)$} \\
\hline & \multicolumn{5}{|c|}{ Nitrogen supply form } \\
\hline & Control & $80 \mathrm{~N}$ & A. brasilense & R. tropici & A. brasilense $+R$. tropici \\
\hline Recommended & $52.76 \mathrm{ABa}$ & $56.86 \mathrm{Aa}$ & $52.94 \mathrm{ABa}$ & $54.06 \mathrm{ABa}$ & $51.19 \mathrm{Bb}$ \\
\hline $75 \%$ of the recommended & $51.19 \mathrm{Ba}$ & $54.29 \mathrm{ABa}$ & $52.20 \mathrm{ABa}$ & $53.92 \mathrm{ABa}$ & $55.90 \mathrm{Aa}$ \\
\hline
\end{tabular}


$R$. tropici and co-inoculation in beans grown in the rainy season of 2009/2010 in Londrina, for the content of $\mathrm{N}$ in the aerial part.

When unfolding the nitrogen supply form within irrigation depth, it is found that the application of $80 \mathrm{~kg} \mathrm{ha}$ ${ }^{1}$ of $\mathrm{N}$ in topdressing was higher than co-inoculation alone, for the leaf nitrogen content in 2013 in the recommended depth. In the depth of $75 \%$ of the recommended, coinoculation resulted in greater nitrogen content than the control treatment. As for the water depth in the nitrogen supply form, co-inoculation with the recommended depth provided lower leaf nitrogen content than the depth of $75 \%$ of the recommended (Table 2). In contrast to the results obtained in this work, Veronezi et al. (2012) did not find any differences when evaluating the leaf nitrogen content according to the control without inoculation, nitrogen control, inoculation with Rhizobium and coinoculation. Pelegrin et al. (2009), when analyzing the effect of doses of 40 and $80 \mathrm{~kg} \mathrm{ha}^{-1} \mathrm{~N}$ as urea and inoculation of Rhizobium tropici combined or not with application of 20 $\mathrm{kg} \mathrm{ha}^{-1}$ of $\mathrm{N}$ at sowing, found no differences in the content of $\mathrm{N}$ in the aerial part.

These different effects between the two years may be the result from the fact that they are factors (bacteria, nitrogen fertilizer and plant) influenced by environmental conditions, mainly temperature and rainfall.

The number of nodules and dry matter mass of nodules per plant were not affected by treatments in 2012. However, in 2013, the form of nitrogen supply resulted in a significant difference (Table 3). Inoculation of seeds with A.brasilense $+R$. tropici increased the number and mass of dry matter of nodules in 2013 (Table 3). Burdman et al. (1997) studied the effect of co-inoculation in seeds of beans, cv. Bulgarian, in laboratory conditions, and obtained an increase in the number of nodules with the co-inoculation (Rhizobium + Azospirillum) in relation to the inoculation of Rhizobium alone. This effect may occur because of the fact that when Azospirillum is associated with Rhizobium, it produces more flavonoid signs (Dardanelli et al., 2008), a substance that attracts rhizobia to the roots of the beans.

In the years 2012 and 2013, the form of nitrogen supply affected the number of pods. In 2012, the lowest number of pods was obtained with the control and $80 \mathrm{~kg} \mathrm{ha}^{-1}$ of nitrogen in topdressing, but they were similar to inoculation of seeds with Azospirillum and Rhizobium (Table 3). Similarly, Soares (2012) did not find any differences in the number of bean pods among the following treatments: non-inoculated, inoculated with $R$. tropici, inoculated with $R$. tropici and fertilized, and fertilized only in the winter/spring crops of 2010. Gitti et al. (2012) found no differences between the seeds of beans inoculated and non-inoculated with Azospirillum brasilense on the number of pods. In the year of 2013, the co-inoculation and $R$. tropici treatments resulted in a smaller number of pods (Table 3 ). In both years, the number of pods was not influenced by water depth. Likewise, Arf et al. (2004) and Soratto et al. (2003) found no differences in the number of pods per plant when water depths were compared: recommended, $75 \%$ of the recommended and $125 \%$ of the recommended.

As for the number of grains per pod, it is observed that the form of nitrogen supply had no effect in both years, only the water depth in 2012 (Table 3), whose water depth of $75 \%$ of the recommended was able to produce greater number of seeds per pod. The results observed for the form of nitrogen supply corroborate those obtained by Araújo et al. (2007), who found no differences between the control without inoculation, nitrogen fertilization and inoculation with Rhizobium tropici on the number of grains per pod. On the other hand, Soratto et al. (2003) reported no differences in the number of grains per pod with the recommended water depths, water depth of $75 \%$ of the recommended and $125 \%$ of the recommended.

Nitrogen supply form had effect on supply on 100grain mass in both evaluated years. In 2012, R. tropici resulted in lower grain mass than to $80 \mathrm{~kg} \mathrm{ha}^{-1}$ of topdressing nitrogen, and in 2013, the lowest weight of 100 -grain mass was obtained with the co-inoculation compared to control, $80 \mathrm{~kg} \mathrm{ha}^{-1}$ of $\mathrm{N}$ in topdressing and $A$. brasilense. The water depth did not affect 100-grain mass in both years (Table 3). Ferreira et al. (2000) reported that there was no influence of inoculation of $R$. tropici reference strain (inoculation $+10 \mathrm{~kg} \mathrm{ha}^{-1} \mathrm{~N}$ at sowing) on the 100 grain mass in relation to the no- inoculation without nitrogen fertilization and the nitrogen fertilization. The results obtained by Arf et al. (2004) and Soratto et al. (2003) corroborate those obtained in this experiment, whose 100 -grain mass was not affected by the depths of the recommended irrigation and $75 \%$ of the recommended.

Grain yield in 2012 and 2013 was not influenced by the form of nitrogen supply (Table 3). These results are in agreement with those obtained by Souza et al. (2011), who found that yield is not affected by inoculation of Rhizobium tropici in the seeds and is little influenced by nitrogen fertilization. On the other hand, Hungria et al. (2013), when conducting five experiments in two locations (Londrina and Ponta Grossa) for three growing seasons (2009, 2010 and 2010/11) obtained higher yield with the co-inoculation and non-inoculated control and fertilized compared to noninoculated control and not fertilized, inoculation with Rhizobium and application of Azospirillum in the furrows.

Likewise, yield was not influenced by the irrigation depths (Table 3). Other authors have also reported similar results, where yield was not affected by depths of $75 \%$ of the recommended and the recommended depth in experiments conducted by Arf et al. (2004) and Soratto et al. (2003). 
Table 3: Number of nodules per plant (NN), nodule dry matter mass per plant (NDM), number of pods (NP), number of grains per pod (NGP), 100-grain mass (M100) and grain yield (GY) of Pérola beans according to nitrogen supply and irrigation depths

\begin{tabular}{|c|c|c|c|c|c|c|c|c|c|c|c|c|}
\hline \multirow[t]{2}{*}{ Treatments } & \multicolumn{2}{|c|}{ NN (no. plant ${ }^{-1}$ ) } & \multicolumn{2}{|c|}{ NDM (g) } & \multicolumn{2}{|c|}{$\mathbf{N P}\left(\right.$ no. plant $\left.^{-1}\right)$} & \multicolumn{2}{|c|}{ NGP (no. pod $\left.{ }^{-1}\right)$} & \multicolumn{2}{|c|}{ M100 (g) } & \multicolumn{2}{|c|}{ GY (kg ha-1) } \\
\hline & 2012 & 2013 & 2012 & 2013 & 2012 & 2013 & 2012 & 2013 & 2012 & 2013 & 2012 & 2013 \\
\hline & \multicolumn{12}{|c|}{ IRRIGATION DEPTH } \\
\hline Recommended depth & 14.70 & 24.81 & 0.068 & 0.027 & 10.64 & 10.21 & $4.79 b$ & 5.21 & 27.91 & 26.02 & 2,186 & 2,081 \\
\hline $75 \%$ of the recommended depth & 14.67 & 30.81 & 0.074 & 0.036 & 10.26 & 11.24 & $4.99 \mathrm{a}$ & 5.27 & 28.26 & 25.92 & 2,154 & 2,327 \\
\hline \multirow[t]{2}{*}{ MSD } & 4.79 & 20.10 & 0.038 & 0.025 & 1.58 & 1.57 & 0.16 & 0.15 & 0.53 & 1.90 & 260 & 360 \\
\hline & \multicolumn{12}{|c|}{ NITROGEN SUPPLY FORM } \\
\hline Control & 12.80 & $19.55 b$ & 0.069 & $0.030 \mathrm{~b}$ & $9.34 b$ & $12.31 \mathrm{a}$ & 4.84 & 5.43 & 27.71ab & $26.47 \mathrm{a}$ & 2,198 & 2,301 \\
\hline $80 \mathrm{~kg} \mathrm{~N} \mathrm{ha}^{-1}$ topdressing & 15.75 & $20.26 b$ & 0.060 & $0.021 b$ & $9.31 \mathrm{~b}$ & $11.70 \mathrm{a}$ & 4.96 & 5.23 & $28.87 \mathrm{a}$ & $26.47 \mathrm{a}$ & 2,112 & 2,367 \\
\hline Azospirillum brasilense & 13.55 & $31.80 \mathrm{~b}$ & 0.073 & $0.025 b$ & $10.47 \mathrm{ab}$ & $11.68 \mathrm{a}$ & 5.04 & 5.25 & $28.34 \mathrm{ab}$ & $26.37 \mathrm{a}$ & 2,009 & 2,101 \\
\hline Rhizobium tropici & 15.85 & $19.32 \mathrm{~b}$ & 0.071 & $0.021 b$ & $10.95 \mathrm{ab}$ & $9.18 b$ & 4.88 & 5.15 & $27.20 \mathrm{~b}$ & $25.93 \mathrm{a}$ & 2,343 & 2,109 \\
\hline A. brasilense $+R$. tropici & 15.47 & $48.12 \mathrm{a}$ & 0.083 & $0.059 \mathrm{a}$ & $12.17 \mathrm{a}$ & $8.75 \mathrm{~b}$ & 4.73 & 5.12 & $28.32 \mathrm{ab}$ & $24.63 b$ & 2,189 & 2,143 \\
\hline MSD & 4.06 & 14.20 & 0.031 & 0.028 & 1.87 & 1.90 & 0.37 & 0.39 & 1.55 & 1.19 & 408 & 386 \\
\hline \multicolumn{13}{|l|}{$\mathbf{F}$} \\
\hline Blocks (B) & $0.855^{\mathrm{ns}}$ & $0.070^{\mathrm{ns}}$ & $0.132^{\mathrm{ns}}$ & $0.123^{\mathrm{ns}}$ & $0.383^{\mathrm{ns}}$ & $0.242^{\mathrm{ns}}$ & $3.455^{\mathrm{ns}}$ & $2.300^{\mathrm{ns}}$ & $0.239^{\mathrm{ns}}$ & $0.109^{\mathrm{ns}}$ & $1,397^{\mathrm{ns}}$ & $0,245^{\mathrm{ns}}$ \\
\hline Depths (D) & $0.001^{\mathrm{ns}}$ & $1.651^{\mathrm{ns}}$ & $0.514^{\mathrm{ns}}$ & $2.511^{\mathrm{ns}}$ & $0.604^{\mathrm{ns}}$ & $4.410^{\text {ns }}$ & $17.163^{*}$ & $1.703^{\mathrm{ns}}$ & $4.577^{\mathrm{ns}}$ & $0.025^{\mathrm{ns}}$ & $0,147^{\text {ns }}$ & $4,748^{\mathrm{ns}}$ \\
\hline CV $1(\%)$ & 20.77 & 46.01 & 33.60 & 50.91 & 14.99 & 14.55 & 3.17 & 2.75 & 1.86 & 7.27 & 11,89 & 16,24 \\
\hline $\mathrm{N}$ supply form (NSF) & $2.260^{\mathrm{ns}}$ & $14.580^{* *}$ & $1.269^{\mathrm{ns}}$ & $6.227^{* *}$ & $7.114^{* *}$ & $12.871^{* *}$ & $1.674^{\mathrm{ns}}$ & $1.681^{\mathrm{ns}}$ & $3.003^{*}$ & $7.554^{* *}$ & $1,572^{\mathrm{ns}}$ & $1,730^{\mathrm{ns}}$ \\
\hline (L) $\mathrm{x}(\mathrm{NSF})$ & $2.104^{\mathrm{ns}}$ & $2.657^{\mathrm{ns}}$ & $1.469^{\mathrm{ns}}$ & $0.082^{\mathrm{ns}}$ & $0.996^{\text {ns }}$ & $1.188^{\mathrm{ns}}$ & $0.895^{\mathrm{ns}}$ & $1.254^{\mathrm{ns}}$ & $1.260^{\mathrm{ns}}$ & $0.591^{\mathrm{ns}}$ & $0,071^{\mathrm{ns}}$ & $1,875^{\mathrm{ns}}$ \\
\hline CV $2(\%)$ & 15.64 & 28.85 & 24.97 & 50.27 & 12.16 & 12.01 & 5.17 & 5.08 & 3.75 & 3.11 & 12,75 & 11,88 \\
\hline Average & 14.68 & 27.81 & 0.071 & 0.031 & 10.45 & 10.72 & 4.89 & 5.24 & 28.09 & 25,97 & 2,170 & 2,204 \\
\hline
\end{tabular}

**, * and ${ }^{\mathrm{ns}}-$ significant at 1 and $5 \%$ of probability and non-sifinifcant by the $\mathrm{F}$ test, respectively;

Means followed by the same letter in the columns do not differ by the test of Tukey at $5 \%$ of probability;M.S.D. - minimum significant difference; C.V. - coefficient of variation 


\section{CONCLUSIONS}

Co-inoculation provided an increase in the nodulation in the second year of cultivation.

None of the evaluated treatments increased yield in relation to the non-inoculated control with $40 \mathrm{~kg} \mathrm{ha}^{-1}$ of nitrogen in topdressing.

The use of $75 \%$ of the recommended water depth provided grain yield similar to the recommended water depth in winter beans crop.

\section{REFERENCES}

Ambrosano EJ, Wutke EB, Bulisani EA \& Cantarella H (1997) Feijão. In: Raij BV, Cantarella H, Quaggio JÁ \& Furlani ÂMC (Eds.) Recomendações de adubação e calagem para o Estado de São Paulo. Campinas, Instituto Agronômico/Fundação- IAC. p.194-195

Araújo FF, Carmona FG, Tiritan CS \& Creste JE (2007) Fixação biológica de $\mathrm{N}_{2}$ no feijoeiro submetido a dosagens de inoculante e tratamento químico na semente comparado à adubação nitrogenada. Acta Scientiarum Agronomy, 29:535-540.

Araújo FF \& Hungria M (1999) Nodulação e rendimento de soja co-infectada com Bacillus subtilis e Bradyrhizobium japonicum/ Bradyrhizobium elkani. Pesquisa Agropecuária Brasileira, 9:1633-1643

Arf O, Rodrigues RAF, Sá ME, Buzetti S \& Nascimento V (2004) Manejo do solo, água e nitrogênio no cultivo de feijão. Pesquisa Agropecuária Brasileira, 39:131-138.

Arf MV, Buzetti S, Arf O, Kappes C, Ferreira JP, Gitti DC \& Yamamoto CJ (2011) Fontes e épocas de aplicação de nitrogênio em feijoeiro de inverno sob sistema plantio direto. Pesquisa Agropecuária Tropical, 41:430-438.

Bárbaro IM, Brancalião SR, Ticelli M, Miguel FB \& Silva JAA (2008) Técnica alternativa: co-inoculação de soja com Azospirillum e Bradyrhizobium visando incremento de produtividade. Artigo em Hypertexto. Disponível em: <http:// www.infobibos.com/Artigos/2008_4/coinoculacao/index.htm>. Acessado em: 04 de janeiro de 2012 .

Bashan Y \& Bashan LE (2005) Bacteria/Plant Growth-Promoting. In: Hillel D (Ed.) Encyclopedia of soils in the environment. Oxford, Elsevier. p.103-115.

Burdman S, Kigel J \& Okon Y (1997) Effects of Azospirillum brasilense on nodulation and growth of common bean (Phaseolus vulgaris L.). Soil Biology \& Biochemistry, 29:923-929.

Chibeba AM, Guimarães MF, Brito OR, Nogueira MA, Araujo RS \& Hungria M (2015) Co-inoculation of soybean with Bradyrhizobium and Azospirillum promotes early nodulation. American Journal of Plant Science, 6:1641-1649.

Companhia Nacional de Abastecimento - Conab (2015) Séries históricas: Feijão $1^{\mathrm{a}}, 2^{\mathrm{a}}$ e $3^{\mathrm{a}}$ safra. Disponível em: <www.conab.gov.br〉. Acessado em: 20 de dezembro de 2015.

Costa EM, Carvalho F, Esteves JA, Nóbrega RSA \& Moreira FMS (2014) Resposta da soja a inoculação e co-inoculação com bactérias promotoras do crescimento vegetal e Bradyrhizobium. Enciclopédia Biosfera, 10:1678-1689.

Dardanelli MS, Fernandez de Córdoba FJ, Espuny MR, Carvajal MAR, Díaz MES, Serrano AMG, Okon Y \& Megías M (2008) Effect of Azospirillum brasilense coinoculated with Rhizobium on Phaseolus vulgaris flavonoids and Nod factor production under salt stress. Soil Biology \& Biochemistry, 40:2713-2721.
Doorenbos J \& Pruitt WO (1976) Las necesidades de agua de los cultivos. Roma, FAO. 193p.

Doorenbos J \& Kassam AH (1979) Yield response to water. Roma, FAO. 193p. (Irrigation and Drainage Paper, 33)

Embrapa - Empresa Brasileira de Pesquisa Agropecuária (2006) Centro Nacional de Pesquisa de Solos. Sistema brasileiro de classificação de solos. $2^{a}$ ed. Rio de Janeiro, Embrapa Solos. $306 \mathrm{p}$.

Ferlini HÁ (2006) Co-Inoculación en Soja (Glicyne max) con Bradyrhizobium japonicum y Azospirillum brasilense. Artículos Técnicos - Agricultura. Disponível em: <http:// www.engormix.com/co_inoculacion_soja_glicyne_s_articulos 800_AGR.htm>. Acessado em: 10 de janeiro de 2012.

Fernandez F, Gepts P \& Lopes M (1986) Etapas de desarrollo de la planta de frijol (Phaseolus vulgaris L.). Cali, Centro Internacional de Agricultura Tropical. 34p.

Ferreira DF (2011) SISVAR: a computer statistical analysis system. Ciência e Agrotecnologia, 35:1039-1042.

Ferreira NA, Arf O, Carvalho MAC, Araújo RS, Sá ME \& Buzetti S (2000) Estirpes de Rhizobium tropici na inoculação do feijoeiro. Scientia Agricola, 57:507-512.

FAO - Food And Agriculture Organization (2014) Faostat 2014. Disponível em: <http://faostat.fao.org>. Acessado em: 5 de janeiro de 2015

Gitti DC, Arf O, Kaneko FH, Rodrigues RAF, Buzetti S, Portugal JR \& Corsini DCDC (2012) Inoculação de Azospirillum brasilense em cultivares de feijões cultivados no inverno. Revista Agrarian, $5: 36-46$

Groppa MD, Zawoznik MS \& Tomaro ML (1998) Effect of coinoculation with Bradyrhizobium japonicum and Azospirillum brasilense on soybean plants. European Journal of Soil Biology, 34:75-80

Hungria M, Campo RJ \& Mendes IC (2007) A importância do processo de fixação biológica do nitrogênio para a cultura da soja: componente essencial para a competitividade do produto brasileiro. Londrina, Embrapa Soja. 80p. (Documentos, 283)

Hungria M \& Nogueira MA (2013) Efeitos da co-inoculação. Cultivar Grandes Culturas, 170:40-41.

Hungria M, Nogueira MA \& Araujo RS (2013) Co-inoculation of soybeans and common beans with rhizobia and azospirilla: strategies to improve sustainability. Biology and Fertility of Soils, 49:791-801.

Hungria M, Nogueira MA \& Araujo RS (2015) Soybean seed coinoculation with Bradyrhizobium spp. and Azospirillum brasilense: a new biotechnological tool to improve yield and sustainability. American Journal of Plant Sciences, 6:811-817.

Hungria M \& Vargas MAT (2000) Environmental factors affecting $\mathrm{N}_{2}$ ûxation in grain legumes in the tropics, with an emphasis on Brazil. Field Crops Research, 65:151-164.

Malavolta E, Vitti GC \& Oliveira AS (1997) Avaliação do Estado Nutricional das Plantas: princípios e aplicações. Piracicaba, Potafós. 319p.

Oliveira JP, Silva MLRB, Lira MCCP \& Burity HA (2008). Fixação do $\mathrm{N}_{2}$ associativa e em vida livre. In: Figueiredo MVB, Burity HA, Stamford NP \& Santos CERS (Eds.) Microrganismos e agrobiodiversidade: o novo desafio para a agricultura. Guaíba, Agrolivros. p.97-118.

Paula Júnior TJ, Vieira RF, Teixeira H, Coelho RR, Carneiro JES, Andrade MJB \& Rezende AM (2008) Informações técnicas para o cultivo do feijoeiro-comum na região central brasileira: 20072009. Viçosa, EPAMIG-CTZM. 180p. (Documentos, 42) 
Pelegrin R, Mercante FM, Otsubo IMN \& Otsubo AA (2009) Resposta da cultura do feijoeiro à adubação nitrogenada e à inoculação com rizóbio. Revista Brasileira de Ciência do Solo, $33: 219-226$.

Portugal JR, Peres AR \& Rodrigues RAF (2015) Aspectos climáticos no feijoeiro. In: Arf O, Lemos LB, Soratto RP \& Ferrari S (Eds.) Aspectos gerais da cultura do feijão Phaseolus vulgaris L. Botucatu, FEPAF. p.65-75.

Reis VM (2007) Uso de bactérias fixadoras de nitrogênio como inoculante para aplicação em gramíneas. Seropédica, Embrapa Agrobiologia. 22p. (Documentos 232)

Soares BL (2012) Avaliação técnica e econômica do feijoeirocomum inoculado com rizóbio em diferentes ambientes. Tese de Doutorado. Universidade Federal de Lavras, Lavras. 151p.

Soratto RP, Arf O, Rodrigues RAF, Buzetti S \& Silva TRB (2003) Resposta do feijoeiro ao preparo do solo, manejo de água e parcelamento do nitrogênio. Acta Scientiarum. Agronomy, 25:89-96

Souza AB, Andrade MJB, Muniz JA \& Reis RP (2002) Populações de plantas e níveis de adubação e calagem para o feijoeiro (Phaseolus vulgaris L.) em um solo de baixa fertilidade. Ciência e Agrotecnologia, 26:87-98.
Souza GS, Matoso SCG, Silva JB \& Pintar AF (2012) Nodulação e crescimento do feijoeiro Pérola em resposta à aplicação de molibdênio e solução de quefir. In: $2^{\circ}$ Seminário de Iniciação Científica, Colorado do Oeste. Anais, IFECTR/IFRO. p.1-3.

Souza EFC, Soratto RP \& Pagani FA (2011) Aplicação de nitrogênio e inoculação com rizóbio em feijoeiro cultivado após milho consorciado com braquiária. Pesquisa Agropecuária Brasileira, 46:370-377.

Veronezi SDF, Costa MR, Silva AT \& Mercante FM (2012) Coinoculação de rizóbio e Azospirillum brasilense em feijoeiro (Phaseolus vulgaris L.) In: $4^{\circ}$ Seminário de Agroecologia de Mato Grosso do Sul, $3^{\circ}$ Encontro de Produtores Agroecológicos de MS, Glória de Dourados. Anais, Embrapa. p.1-5.

Yadegari M, Rahmani HA, Noormohammadi G \& Ayneband A (2010) Plant growth promoting rhizobacteria increase growth, yield and nitrogen fixation in Phaseolus vulgaris. Journal of Plant Nutrition, 33:1733-1743.

Yadegari M (2014) Inoculation of bean (Phaseolus vulgaris) seeds with Rizobium phaseoli and plant growth promoting rhizobacteria. Advances in Environmental Biology, 8:419-424. 